\title{
TINJAUAN YURIDIS PREDATORY PRICING QLEH PELAKU USAHA RESELLER KARTU PAKET INTERNET DITINJAU DARI UNDANG-UNDANG ND. 5 TAHUN 1999 (STUDI: DI KDMPLEK MMTC JALAN PANCING MEDAN)
}

\author{
Lesson Sihotang', Ricky Dmega Yosua ${ }^{2}$ \\ Fakultas Hukum Universitas HKBP Nammensen, Medan \\ sihntangmarsait78国gmail.com
}

\begin{abstract}
Info Artikel
Diterima : 18 September 2020

Revisi : 22 Oktober 2020

Terbit : 18 Desember 2020
\end{abstract}

\section{Key wards:}

Legal Analysis, Perpetrators, and Predatary Pricing

\section{Kata Kunci:}

Tinjauan Yuridis, Pelaku Usaha, Jual Rugi (Predatory Pricing)

\section{Corresponding Author :}

Lesson Sihatang, E-mail : sihotangmarsoit78回gmail.com

\begin{abstract}
Predatory Pricing is the act of a company setting prices below the cost of production in order to eliminate competitors. The study of the law is by predatory pricing by an Internet raffle card in the MMTC complex and section 5 and 8 links to pricing arranged in 1999's statute no. 5 on monopoly and improper business competition. The aim of the study is to find out the adverse effects of the reseller of Internet package Cards and to learn about the pricing of those governed in 1999's statute no. 5 regarding monopoly and unhealthy business competition. This legal research is taken from a normative-empirical legal approach. This approach will merge data that comes from library research and data obtained in the field. Normative data will be generated in legal literature, legal books, legal journals and other materials. While empirical data will be obtained from an interview with the perpetrators of an Internet package card. This legal study will address the indelicate effects of the Internet package card business and the relationships chapters 5 and 8 on pricing under 1999 law no.5. The end of this legal study will be to learn more about the cost of the undergraduate work.
\end{abstract}




\section{PENDAHULLAN}

Penerapan tarif yang terlalu rendah dapat memicu terjadinya persaingan tidak sehat, dikarenakan pelaku usaha dapat membuat pesaingnya tidak dapat bersaing secara kompetitif. Dengan tidak adanya persaingan usaha, pelaku usaha yang memiliki posisi dominan ini dapat mempermainkan jumlah barang maupun jasa yang tersedia.

Menurut hukum positif Indonesia yang terdapat dalam Pasal 25 ayat (2) point a undang-undang anti monopoli dan persaqingan usaha tidak sehat menyebutkan satu pelaku usaha atau kelompok pelaku usaha dapat dikategorikan melakukan posisi dominan apabila telah menguasai lebih 50\% (lima puluh persen) pangsa pasar satu jenis barang atau jasa.'

Kondisi dalam dunia usaha banyak diwarnai oleh perilaku usaha yang tidak sehat. Pelaku usaha cenderung memupuk insentif untuk mendapatkan kekuatan pasar dan memperoleh keleluasaan mengendalikan harga. Dalam menciptakan kekuatan pasar tersebut, pelaku usaha melakukan tindakan-tindakan yang merugikan pesaingnya, seperti melakukan pembatasan pasar (market restriction), membuat rintangan perdagangan (barrier to entry).

Masuk pasar, mengadakan kesepakatan kolusif (collusive agreements) untuk mengatur harga, membatasi output, mengatur pasar, dan menjalankan praktek anti persaingan lainnya. Istilah "pelaku usaha" diatur dalamPasal I angka $5 \mathrm{LU}$ Nomor 5 Tahun 1999 yaitu, bahwa pelaku usaha adalah setiap orang perorangan atau badan usaha, baik yang berbentuk badan hukum atau bukan badan hukum yang didirikan dan berkedudukan atau melakukan kegiatan dalam wilayah Negara hukum, baik sendiri maupun bersama-sama melalui perjanjian, menyelenggarakan berbagai kegiatan usaha dalam bidang ekonami.

Banyak kasus praktek monopdi yang akan terjadi karena ketidakseimbangan pasar paket internet tersebut. Banyak faktor yang menyebabkan pelaku usaha melakukan praktek monopoli salah satunya dikarenakan kurangnya pengawasan peraturan pemerintah. Beberapa peraturan atau perundang-undangan secara langsung menyebabkan terjadinya pasar monopoli untuk jenis barang atau jasa tertentu. Praktek yang terjadi dengan adanya Kegiatan penjualan paket internettersebut adalah praktek Jual Rugi (Predatory Pricing). Jual rugi (Predatory Pricing) merupakan salah satu kegiatan yang dilarang secara Rule of Reasan yang memungkinkan pengadilan mempertimbangkan faktor-faktor kompetitif dan menetapkan layak atau tidaknya suatu hambatan perdagangan. Artinya untuk mengetahui apakah hambatan tersebut bersifat mencampuri, mempengaruhi, atau bahkan menghambat proses persaingan.

\section{METDDE PENELITIAN}

Jenis penelitian ini adalah penelitian yuridis empiris, yaitu bahwa dalam menganalisis permasalahan dilakukan dengan cara memadukan bahan-bahan hukum (yang memadukan data sekunder) dengan data primer yang diperoleh di lapangan tentang pelaksanaan diperusahaan yang bergerak dibidang industri, yang berskala kecil, menengah, dan besar. Di dalam penelitian ini akan memfokuskan pada hal-hal apa yang terjadi setelah adanya persaingan usaha tidak sehat yang dilakukan oleh pelaku usaha dalam meningkatkan daya tarik konsumen dan apakah dengan diterapkannya prinsip jual rugi (Predatory Pricing) pelaku usaha tersebut dapat

'Simulasikredit.com, Apa Itu Predatory Pricing? Strategi Penetapan Harga Predatory

https://www.simulasikredit.com/apa-itu-Predatory-pricing-strategi-penetapan-harga-Predatory/ diakses pada 7 Maret 2020

Tinjauan Yuridis Predatary Pricing Dleh Pelaku Usaha Reseller Kartu Paket Internet Ditinjau Dari Undang-Undang No. 5 Tahun 1999 (Studi: Di Kamplek Mmtc dalan Pancing Medan) 
memperoleh keuntungan yang sebesar-besarnya atau justru mengalami kerugian. Penelitian hukum tidak mengenal adanya data untuk memecahkan isu hukum dan sekaligus memberikan preskripsi apa yang seharusnya diperlukan untuk sumber-sumber penelitian. Data yang dikumpulkan dalam penelitian ini ialah data sekunder, antara lain mencakup dokumen-dokumen resmi, buku-buku, hasil-hasil penelitian yang berwujud laporan, buku harian, dan seterusnya Sumber-sumber penelitian hukum dapat dibedakan menjadi sumber-sumber penelitian yang berupa bahan hukum primer, sekunder, dan tertier.

\section{HASIL DAN PEMBAHASAN}

Saat ini internet menjadi kebutuhan masyarakat setiap tahun nуa pengguna kartu paket internet meningkat sebesar 7,6\% di dunia. Dengan tidak memandang usia digunakan di berbagai media elektranik seperti, Komputer, Tablet dan Telepan Genggam. Di Indonesia pengguna kartu paket internet sudah mencapai 61\% dari total penduduk Indanesia karena tuntutan zaman inilah masyarakat membutuhkan kartu paket internet dengan harga yang terjangkau. Namun di Medan Sumatera Utara yang berada di Kamplek MMTC Jalan Pancing penjualan kartu paket internet tergolong unik para pelaku usaha kartu paket internet kebanyakan menjual kartu paket internet menggunakan mobil dan juga ada pelaku usaha yang membuka lapak kecil yang ada di sisi jalan khususnya juga ditempat ramai seperti pasar dan juga lokasi perkuliahan dan bisnis penjualan kartu paket internet ini sudah menjamur selama lebih empat tahun dan bagi para pelaku usaha para penjual kartu paket internet ini tidak memiliki jam operasional, karena mereka hanya berjualan ketika pada jam anak sekolah dan anak perkuliahan.

Bisnis usaha ini sangat pesat selama empat tahun terakhir dan para pelaku usaha kartu paket internet menawarkan kuota kartu paket internet yang sangat murah demi menarik para konsumen saling bersaing di usaha yang sama. Umumnya para pelaku usaha penjualan kartu paket internet ini dapat menjual sebanyak 70 kartu paket internet dengan berbagai jenis provider dengan harga yang cukup bervariasi dari jam sepuluh pagi hingga jam sepuluh malam. Keberadaan pelaku usaha penjualan kartu paket internet di kamplek MMTC ini sangat membantu khususnya dikalangan mahasiswa yang lokasinya sangat berdekatan dengan kampus yang harga kartu paket internet jauh lebih murah daripada membeli langsung di toko kartu paket internet. Namun pelaku usaha yang membuka toko kartu paket internet juga antusias untuk menawarkan harga yang murah agar konsumen juga tertarik dan akhirnya juga menimbulkan persaingan usaha yang tidak sehat terhadap pelaku usaha kecil.

\section{Indikasi Jual Rugi ${ }^{2}$}

Berdasarkan teari ekanomi, jual rugi adalah suatu kondisi di mana suatu pelaku usaha menetapkan harga jual dari barang dan atau jasa yang diproduksinya di bawah biaya total rata-rata (Average Total Cost). Suatu pelaku usaha hanya akan memperoleh keuntungan jika ia dapat menetapkan harga jual barang dan atau jasa yang diproduksinya di atas biaya total rata-rata, atau hanya dapat sekedar menutup biayanya (pulang pokok - break even) bila menetapkan harga persis sama dengan biaya total rata-rata. Tetapi harga yang ditetapkan di bawah biaya total rata-rata (ATC) tersebut tetap masih dapat dikatakan sebagai reasunable price apabila berada di atas biaya variabel rata-rata (average variable cast), karena pada kondisi tersebut tetap masih ada

${ }^{2}$ Peraturan KPPU No. G Tahun 2OIl tentang Pedoman Pasal 20 (Jual Rugi) UU No.5 Tahun 1999

Tinjauan Yuridis Predatary Pricing Dleh Pelaku Usaha Reselller Kartu Paket Internet Ditinjau Dari Undang-Undang No. 5 Tahun I999 (Studi: Di Kamplek Mmtc dalan Pancing Medan) 
gunanya bagi pelaku usaha untuk berproduksi, meskipun tidak ada gunanya untuk mengganti peralatan modal yang sudah rusak. Sedangkan apabila suatu pelaku usaha berproduksi pada harga di bawah biaya variabel ratarata (AVC), maka dapat dikatakan bahwa harga tersebut sudah tidak wajar (reasanable) lagi, dan jual rugi yang dilakukan oleh pelaku usaha tersebut dapat dicurigai mempunyai maksud tertentu. Dari hasil wawancara yang terindikasi melakukan Kegiatan Jual Rugi diketahui bahwa penjualan yang melakukan kegiatan jual rugi itu tidak ada. Yang terjadi adalah harga dari distributar terkadang berubah-ubah tidak selalu sama pada setiap bulannya. dan juga melakukan kegiatan ini disaat tertentu saja, contohnya jika ada produk baru Kartu Paket Internet maka dilakukan penjualan harga di bawah normal. Dimana tujuannya ialah untuk menarik knnsumen agar produk baru ini dapat dinikmati oleh konsumen-kansumen yang sering membeli kartu paket internet di toko dan sebagai promosi juga terhadap kartu paket internet yang baru muncul tersebut. ${ }^{3}$

Dalam hal ini, peneliti juga melakukan perbandingan wawancara dengan pelaku usaha kecil yang dianggap korban.Yang merasakan rugi dan kalah dalam persaingan penjualan paket internet ini mengatakan, "mereka yang menjual harga di bawah normal menurut responden ini adalah untuk menarik kansumenkami ini yang usahanya kecil, sehingga knnsumen lebih tertarik dengan penawaran yang mereka berikan, jadi kami ini selaku pelaku usaha kecil merasa geram karena mereka hanya memikirkan keuntungan mereka saja, yaitu mengejar point target dalam penjualan seperti asset mobil, rumah dan sebagainya.

Dari hasil wawancara yang penulis lakukan diketahui " harga untuk satu jenis paket yang dijual itu berdasarkan harga pribadi yang dibuat sendiri.Kalau membuat harga rendah dalam penjualan kartu paket internet yang ada bukan untuk menyingkirkan para pelaku usaha lainnya yang bergerak dibidang yang sama. Di samping itu juga ingin menghabiskan stok kartu paket internet yang belum terjual. Tidak apa keuntungannya tidak besar daripada tidak untung sama sekali ataupun menjadi rugi. Namun untungnya juga tidak besar-besar sekali jika membuat harga dibawah rendah, paling besar keuntungan dalam sehari mencapai 70.000 ribu sampai 100.000 ribu. ${ }^{4}$

Sebaliknya penulis juga melakukan wawancara dengan pelaku usaha kartu paket internet yang tergolong usaha kecil dikatakan "untuk menentukan satu jenis kartu paket internet yang saya jual berdasarkan harga pribadi. Namun harga yangditetapkan juga sebatas normal. Harga normal ini sesuai dengan harga kartu paket internet yang beredar dipasaran. Pelaku bisnis juga mendapatkan keuntungan hanya Rp.2000 sampai dengan Rp.4000 untuk satu jenis kartu paket internet yang dijual."

Penetapan Harga Jual Rugi ${ }^{5}$

Secara umum, jual rugi atau predatary pricing adalah suatu strategi usaha menetapkan harga yang sangat rendah untuk barang dan atau jasa yang dihasilkannya dalam suatu periode yang cukup lama, untuk menyingkirkan pelaku usaha lain yang menjadi pesaing-pesaingnya dari pasar, atau juga untuk menghambat pelaku usaha-pelaku usaha lain masuk ke dalam pasar tersebut. Dalam jangka pendek jual rugi sangat menguntungkan konsumen, namun apabila pelaku usaha pesaing telah berada di luar pasar, maka pelaku usaha tersebut akan bertindak sebagai monopolis yang akan menaikkan harga ke tingkat yang sangat tinggi untuk menutupi kerugian yang diderita sebelumnya. Pada umumnya pelaku usaha yang memberlakukan predatory pricing adalah pelaku usaha incumbent yang tidak ingin ada pelaku usaha pesaing dalam bisnis yang

\footnotetext{
${ }^{3}$ Wisman Hasibuan selaku Pemilik Toko Penjualan Kartu Paket Internet

${ }^{4}$ Wisman Hasibuan selaku pemilik toko Kartu Paket Internet
} 
dilakukannya. Agar pelaku usaha pesaingnya ke luar dari pasar atau agar pesaing baru tidak masuk ke dalam pasar, suatu pelaku usaha incumbent akan menetapkan harga barang atau jasa yang diproduksinya di bawah biaya yang dikeluarkannya, agar pelaku usaha pesaingnya itu tidak dapat bertahan dalam bisnis yang sama.

Dalam jangka pendek, jual rugi sangat menguntungkan konsumen karena harga barang yang murah, namun apabila seluruh pesaing tidak dapat melakukan kegiatan usahanya lagi, maka pelaku usaha incumbent akan menaikkan harga ke tingkat yang tinggi untuk menutupi kerugian yang diderita pada saat penetapan harga sangat rendah. Selanjutnya, apabila ada pelaku usaha baru yang ingin ikut menikmati keuntungan akibat harga menjadi tinggi tersebut, maka pelaku usaha incumbent akan kembali menurunkan harga ke tingkat yang sangat rendah untuk menyingkirkan pelaku usaha baru tersebut dari lahan bisnisnya. Hal ini berdampak bahwa tidak akan ada satu pelaku usaha pun yang dapat masuk ke pasar, dan pelaku usaha incumbent bebas menaikkan harga ke tingkat harga monopoli tanpa kuatir diganggu oleh pelaku usahapelaku usaha lain yang akan masuk ke dalam pasar bersangkutan. Dalam beberapa kasus perilaku predatary pricing tidak selalu pelaku usaha monopoli atau incumbent, bahkan juga tidak selalu pelaku usaha yang dominan. Tetapi lebih cenderung salah satu pelaku usaha oligopoli. Bahkan, lebih jauh lagi pelaku usaha predator tidak selalu berusaha menyingkirkan pelaku usaha pesaingnya dari pasar, tetapi lebih untuk mencegah masuknya pesaing-pesaing baru yang potensial ke dalam pasar bersangkutan.

Dari hasil wawancara yang dilakukan diketahui "konsumen yang sudah tetap merasa senang dengan adanya harga kartu paket internet yang jauh lebih murah daripada sebelumnya, karena konsumen atau pelanggan itu pada dasarnya selalu mencari produk murah, serta biasanya paket internet yang saya tawarkan kepada mereka luar biasa pelayanannya. Ketika melihat salah satu jenis kartu paket internet yang murah mereka langsung beralih dari kartu paket internet mereka sebelumnya. Begitulah cara menarik daya pandang mereka ke tok ${ }^{\mathrm{G}}$

Dalam kenyataannya tidak mudah pelaku usaha incumbent untuk menjalankan perilaku predatory pricing. Dleh karena itu perlu dipahami berbagai ciri pelaku usaha yang bertindak sebagai predator tersebut. Selama menjalankan praktik jual rugi, pelaku usaha akan mengalami kerugian yang cukup besar. Dalam kenyataannya, kerugian yang diderita oleh pelaku usaha incumbent akan jauh lebih besar dibandingkan dengan kerugian yang diderita oleh pelaku usaha pesaing dengan tingkat efisiensi yang sama. Hal ini disebabkan oleh karena keharusan pelaku usaha incumbent memenuhi kebutuhan seluruh permintaan pasar pada tingkat harga rendah yang diberlakukannya. Sementara pelaku usaha pesaing tidak dituntut oleh kewajiban seperti itu, sehingga pelaku usaha pesaing dapat mengatur produksinya untuk meminimalkan kerugian. Kerugian pelaku usaha incumbent bahkan akan semakin besar jika pelaku usaha incumbent juga harus memenuhi jumlah produksi yang ditinggalkan pelaku usaha pesaing, atau apabila peningkatan pasar semakin besar. Dengan demikian, jual rugi akan sangat memberatkan bagi pelaku usaha yang ingin memberlakukan praktek predatary pricing.

Apabila sifat industri memungkinkan pelaku usaha pendatang dapat mudah keluar dan masuk pasar, maka tidak akan terjadi praktik predatary pricing. Pada waktu predatory pricing diberlakukan, pelaku usaha pesaing akan ke luar dari pasar bersangkutan dan menginvestasikan asetnya pada industri lain. Ketika pelaku

\footnotetext{
Blbid.

${ }^{6}$ Wisman Hasibuan selaku pemilik toka Kartu Paket Internet
}

Tinjauan Yuridis Predatary Pricing Dleh Pelaku Usaha Reseller Kartu Paket Internet Ditinjau Dari Undang-Undang No. 5 Tahun I99S (Studi: Di Kamplek Mmtc Jalan Pancing Medan) 
usaha incumbent menaikkan harga, maka pelaku usaha pesaing akan kembali masuk ke industri tersebut. Kondisi ini akan berlangsung terus sehingga tidak akan terjadi praktek jual rugi yang pada akhirnya merugikan knnsumen.

Berdasarkan hasil wawancara yang peneliti lakukan bahwa dikatakan "ketika membuat harga rendah pada Penjualan harga Kartu Paket Internet di tokn, itu sah-sah saja jika mau melakukan kegiatan jual rugi dan pasti resiknnya ada, baik dalam keuntungan yang minimum ataupun malah tidak balik sesuai modal awal, namun ditegaskan juga tidak ada niat untuk menjatuhkan pelaku usaha lainnya, ini murni dilakukan karena stok yang kadang menumpuk belum habis terjual di toka kartu paket internet ${ }^{7}$ Peneliti juga melakukan wawancara dengan pelaku usaha kecil lainya bahwa dikatakan "untuk menjual rugi saja tidak sanggup, untung yang dapat saja kecil. Harga yang beredar di pasaran dinaikkan hanya seribu sampai dua ribu setiap untuk satu jenis kartu paket internet ${ }^{\prime \prime}$

Ketika wawancara dengan pelaku usaha kecil lainnya yang juga berada di kamplek MMTC diketahui "menjual kartu paket internet dua puluh buah saja sudah sangat beruntung yang lumayan bisa seratus ribu rupiah. Peneliti juga melakukan wawancara dengan pelaku usaha kecil lainnya bahwa "jual rugi tergantung kebutuhan, mau untung sedikit ataupun membuat harga normal tapi tidak untung sama sekali. Kalau benar mampu membuat harga jual rugi itu sudah menjadi konsekuensi dalam mencapai usaha yang baik atau tidak.Untung juga tidak begitu banyak hanya dua ribu rupiah saja untuk setiap kartu paket internet yang dijual"9 .

\section{KESIMPULAN}

Bahwa kegiatan jual rugi berdasarkan pasal 20 Uل №. 5 Tahun 1999 Pelaku usaha dilarang melakukan pemasokan barang dan atau jasa dengan cara melakukan jual rugi atau menetapkan harga yang sangat rendah dengan maksud untuk menyingkirkan atau mematikan usaha pesaingnya di pasar bersangkutan sehingga dapat mengakibatkan terjadinya praktek monopoli dan atau persaingan usaha tidak sehat. Peneliti berpendapat bahwa jual rugi itu sah selagi kekuatan pasar melemah, disaat itu juga pelaku usaha dapat melakukan jual rugi demi mendapatkan keuntungan yang cukup stabil, namun dengan catatan tanpa harus mengakibatkan pelaku usaha lainnya merasa di rugikan dengan adanya kegiatan jual rugi tersebut.

Dalam persaingan pelaku usaha kartu paket internet yang berada di komplek MMTC bahwa para pelaku usaha banyak yang menetapkan harga produk yang sama. Kondisi ini membuktikan bahwa adanya perjanjian dalam penetapan harga sesuai dengan pasal 5 yang dimana pelaku usaha dilarang untuk membuat perjanjian dengan pelaku usaha pesaingnya untuk menetapkan atas suatu harga barang dan atau jasa. Ada juga beberapa pelaku usaha lainya yang ditemui menjual kartu paket internet dengan harga lebih tinggi kemudian tidak laku maka pelaku usaha menetapkan harga jauh lebih rendah dari harga normal yang beredar dipasaran demi menghabiskan stok barang.

\section{DAFTAR PUSTAKA}

\section{Buku}

Burhan Ashshafa, Metade Penelitian Hukum, Jakarta: Rineka Cipta. 2010.

Gunawan Widjaja, Merger dalam Perspektif Manapoli, Jakarta: Raja Grafinda Persada. 2002.

\footnotetext{
${ }^{7}$ Wisman Hasibuan selaku pemilik toka Kartu Paket Internet

${ }^{8}$ Anisa Muthia Selaku Pelaku Usaha Kecil

${ }^{9}$ Sari Permata Selaku Pelaku Usaha Kecil
}

Tinjauan Yuridis Predatary Pricing Dleh Pelaku Usaha Reseller Kartu Paket Internet Ditinjau Dari Undang-Undang Na. 5 Tahun 1999 (Studi: Di Kamplek Mmtc dalan Pancing Medan) 
Kagramanto, Budi. Mengenal Hukum Persaingan Usaha (Berdasarkan Undang-undang No. 5 Tahun 1999), Sidarjo: Laras. 2008.

Mahmud Mazruki, Metade Penelitian Hukum, dakarta: Prenada Media Group. 2010.

Ningrum Natasya Sirait dkk, Buku Hukum Persaingan Usaha, Jakarta: RDV Creative Media. 2008.

Siswanta, Arie, Hukum Persaingan Usaha, Bogor Selatan: Shalia Indanesia. 2004.

Saekanto Soerjono, dan Sri Mahmudji, Peranan dan Penggunaan Kepustakaan didalam Penelitian Hukum, Jakarta: Pusat Dokumentasi Universitas Indanesia. 1979.

Suyud Margano, Hukum Anti Monopoli, Jakarta: Sinar Grafika. 2009.

\section{Peraturan Perundang-undangan}

Peraturan KPPU No. 6 Tahun 20Il tentang Pedaman Pasal 20 (Jual Rugi) Uل o.5 Tahun 1999

Undang-undang No. 5 Tahun 1999 Tentang Larangan Praktek Monapoli Dan Persaingan Usaha Tidak Sehat.

\section{Skripsi/Tesis}

Skripsi Rezmia Febrina, Dampak Kegiatan Jual Rugi (Predatory Pricing) Yang Dilakukan Pelaku Usaha Dalam Perspektif Persaingan Usaha.

Jurnal

Profesar Attorney. 2017. Predatory Pricing: A Framewark For Analysis. Cit:Baltic Journal of Law \& Politics.

Internet

Dictio, Januari 2018 Apa yang dimaksud dengan prinsip Rule of reason didalam ilmu hukum?https://www.dictio.id/t/apa-yang-dimaksud-dengan-prinsip-rule-of-reasan-didalam-ilmuhukum/14802.

file:///D:/PRDJECT\%2DUHN/New\%2Dfalder/Berkas\%2DSkripsi/jurnal/Bab\%20Il.pdf.

Gede Angga Ari Wardana, Dampak Perang Tarif Promo oleh "Startup" Indanesia, https://muda.kompas.id/baca/2020/Dl/2l/dampak-perang-tarif-promo-oleh-startup-indanesia/.

Hafidzah, "Contoh Kasus Predatory Pricing" http://teentiper.blogspot.com/2012/I2/contoh-kasus-predatortpricing.html?m=l.

http://ejournal.mandalanursa.org/index.php/J|SIP/index

https://makalah-xyz.blogspot.com/2017/I2/persaingan-usaha

https://prezi.com/eelyzfiBjni/predatary-pricing-kasus-indosat/

https://www.hukumanline.com/berita/baca/lt55ff40foedc56/knnsep-ipredatory-pricing-ibisa-dipakaimelihat-persaingan-ojek

https://www.hukumonline.com/klinik/detail/ulasan/tt4b94e668746a9/pentingnya-prinsip-per-se-dan-rule-ofreasun-di-uu-persaingan-usaha/

https://www.pelajaran.co.id/2020/19/pengertian-persaingan-usaha.html

https://www.simulasikredit.com/apa-itu-predatory-pricing-strategi-penetapan-harga-predatory/

lawteacher, The Concept of Predatory Pricing,https://www.lawteacher.net/free-lawessays/commercial-law/the-concept-of-Predatory-pricing.php.

Maxmore, Pengertian Analisa Data,Tujuan,Jenis dan Prosedur Analisis Data,http://www.maxmore.com

Simulasikredit.com, Apa Itu Predatory Pricing? Strategi Penetapan Harga Predatory Pricing, https://www.simulasikredit.com/apa-itu-Predataryy-pricing-strategi-penetapan-harga-Predataryy/. 